\title{
Silvi-kulturella möten: Sveriges lantbruksuniversitet och högre skoglig utbildning i Etiopien 1986-2009
}

\begin{abstract}
Karl Bruno
Abstract • Silvi-Cultural Encounters: The Swedish University of Agricultural Sciences and Higher Forestry Education in Ethiopia, 1986-2009 - The article discusses the Swedish University of Agricultural Sciences' support to higher forestry education in Ethiopia, which took place between 1986 and 2009 in the context of Swedish-Ethiopian development cooperation. Against a growing historical interest in transnational encounters within the field of education, it analyses how Swedish forestry experts designed educational programs and taught in new environments. The concept of "silvi-culture" is introduced to signify that the tensions that arose within this aid effort related both to the technicalities of forestry education and to diverging academic and social cultures. The article is structured around three kinds of "silvi-cultural encounters" that describe the development of the project both chronologically and thematically. These encounters are used to demonstrate how the forest as a concrete, physical place was of central importance to the Swedish experts, as well as to show how they were guided by preconceptions developed within the framework of a Swedish silvi-culture that was only partially compatible with the conditions in Ethiopia.
\end{abstract}

Keywords • development aid [utvecklingsbistånd], forestry education [skogsutbildning], Ethiopia [Etiopien], SLU

\section{Inledning}

I september 1994 fick Wondo Genet College of Forestry i Etiopien prominenta gäster från Sveriges lantbruksuniversitet (SLU). Bland besökarna fanns Per-Ove Bäckström, dekanus för universitetets skogsvetenskapliga fakultet, Görel Oscarsson, universitetets förvaltningschef, och Ann-Cathrin Haglund, dess styrelseordförande. De var där för att övervara invigningen av ett nytt utbildningsprogram, tänkt att leda fram till en skoglig masterexamen för ett utvalt antal etiopiska studenter. ${ }^{1}$ Programmet finansierades med hjälp av svenska biståndsmedel och var en del av ett större samarbete mellan Sveriges biståndsmyndighet SIDA och Etiopien på den skogliga utbildningens område, inom vilket SLU fungerade som konsult. När masterutbildningen invigdes 1994 ansågs den allmänt vara det första egentliga framsteget utvecklingssamarbetet hade gjort sedan det återupptogs efter det etiopiska inbördeskrigets slut 1991. Detta var säkerligen också anledningen till den celebra gästlistan.

Artikeln är baserad på forskningsresultat som tidigare har framlagts i min engelskspråkiga doktorsavhandling: Karl Bruno, Exporting Agrarian Expertise: Development Aid at the Swedish University of Agricultural Sciences and Its Predecessors, 1950-2009 (Uppsala, 2016), kap. 6. Här presenterar jag dem på svenska och i en form som mer tar fasta på det utbildningshistoriska innehållet.

1 Sven-Gunnar Larsson, "Öppnande av Lantbruksuniversitetets utbildningsprogram - Master of Science in Forestry," 18 augusti 1994, SIDA:s biståndskontors i Etiopien arkiv, F72: 28, Riksarkivet (nedan SIDA-ETI).

Karl Bruno is a Postdoctoral Fellow with the Division of History of Science, Technology and Environment, KTH Royal Institute of Technology, Sweden.

Email:kbruno@kth.se 
Den festliga stämningen fick emellertid ett tvärt slut när de nyantagna studenterna revolterade. Studentgruppen skickade ett skarpt formulerat protestbrev till Etiopiens utbildningsminister Genet Zewdie, där de framhöll sin besvikelse både över levnadsförhållandena vid Wondo Genet och över kursplanen och lärarnas erfarenhet. ${ }^{2}$ Studenternas huvudsakliga invändning förefaller ha varit pekuniär: de var missnöjda med den ekonomiska ersättning de skulle få under utbildningstiden. Men deras anspelningar på kursplanen och lärarnas bakgrund låter också förstå att de ansåg att det fanns problem med utbildningskvalitén. Efter kontakter mellan svenska ambassaden, SLU, den etiopiska regeringen, och, så småningom, studenterna, kunde situationen dock lösas, åtminstone så till vida att utbildningen kunde fortsätta som planerat. $^{3}$

Denna episod i spänningsfältet mellan utbildning, bistånd och politik i Etiopien under åren efter inbördeskriget är tänkvärd i sin egen rätt. Här lyfter jag den dock av en annan anledning. Den friktion som uppstod i mötet mellan de etiopiska studenterna och det svenskplanerade utbildningsprogram de var antagna till faller nämligen in i ett större mönster som är utbildningshistoriskt intressant. De ansvariga vid SLU förklarade i efterhand att konflikten var en konsekvens av tidsbrist under kursplaneringen. ${ }^{4}$ Som jag kommer visa låg det emellertid även andra och mer djupgående spänningar bakom den, spänningar som formade de flesta av de aktiviteter som ägde rum under de tjugotre år som det svenska universitetet var engagerat i etiopisk skogsutbildning. Dessa spänningar handlade om hur sådan utbildning bör se ut och gå till, men de var samtidigt mer allmänt kopplade till divergerande akademiska och sociala kulturer. För att illustrera att detta var spänningar som på samma gång handlade om skog och om bredare sociokulturella frågor har jag valt att använda begreppet silvi-kulturella för att beskriva dem, där silvi är det latinska ordet för skog samtidigt som sammansättningen ska leda tankarna till sociokultur (silviculture är dessutom det engelska begreppet för skogsskötsel). I föreliggande artikel kommer jag att beskriva och analysera en uppsättning silvi-kulturella möten som - likt det ovan beskrivna - ägde rum under SLU:s engagemang i etiopisk skogsutbildning. Genom detta vill jag uppmärksamma en lärorik del av senare tids gränsöverskridande utbildningshistoria, mellan skoglig utbildning och utvecklingsbistånd.

\section{Perspektiv, forskningsläge och problem}

Idag uppmärksammas allt mer hur olika utbildningshistorier har varit sammankopplade under tidigmodern och modern tid. I inledningen till en relativt nyutkommen utbildningshistorisk antologi om transnationella utbyten uttrycker redaktörerna att deras syfte är att bredda den "utbildningshistoriska arenan" genom att analysera utbyten och överföringar mellan västvärlden och Asien på utbildningsområdet sedan

2 Aseged Belay et al. till Genet Zewdie, 26 september 1994, SIDA-ETI, F72: 28.

3 Michael Ståhl till Minister of Education, 2 oktober 1994, SIDA-ETI, F72: 28; Ståhl till Sven-Gunnar Larsson, 3 oktober 1994, SIDA-ETI, F72: 28; Ståhl till Minister of Education, 10 oktober 1994, SIDA-ETI, F72: 28; "Report from MSc Coordinator/Liaison Officer for the Period 1994-09-08 to 1994-12-30," 2-3, 2 januari 1995, SIDA-ETI, F72: 29.

4 "Annual Report 1994/95, July, 1994 - June, 1995, Management of Natural Resources in Ethiopia: SIDA Support through the Swedish University of Agricultural Sciences (SUAS)," 6, Oktober 1995, SIDA-ETI, F72: 30. 
1700-talet. ${ }^{5}$ Sådana ansatser tydliggör hur utbildningssystem och ideologier har formats genom möten och utbyten av idéer och materialiteter över nations-, kulturoch språkgränser, och bidrar därmed till att utmana de nationella inriktningar som annars fortfarande har en stark ställning inom det utbildningshistoriska fältet. Att studera gränsöverskridande möten implicerar också att studera dessa mötens rumsliga och materiella kontext. ${ }^{6}$

Även om det renodlade utbildningsbiståndet aldrig har dominerat biståndsbudgetarna har det internationella utvecklingssamarbetet sedan tidig efterkrigstid utgjort en arena av betydelse för transnationella utbildningskontakter. ${ }^{7}$ Biståndets geopolitiska inramning innebar att det i hög grad kom att bli kopplat till stormakternas strävan efter globalt inflytande, vilket gav utbildning en viktig roll. Utbildning, som regel i västlig form, ansågs också centralt för själva utvecklingsbegreppet. Genom både stipendiefinansiering och försök att bygga upp utbildningskapacitet i utvecklingsländer syftade utbildningsbiståndet ytterst till att ersätta tidigare sociala praktiker med nya, moderna sådana. Utifrån idéer om samhällelig utveckling som en universellt likartad process, kopplad till kontroll över vetenskap och teknik, kunde inflytelserika moderniseringsteoretiker som W. W. Rostow avfärda det han beskrev som för-Newtonska samhällens fatalism. Enbart genom att tillägna sig den kunskap och de instrument som krävdes för ett mer rationellt förhållningssätt till världen kunde människor i sådana samhällen ta kontroll över sin egen framtid och förbättra sina levnadsvillkor. ${ }^{8}$ Utifrån detta slags tänkande var det naturligt att planera biståndsprojekt både för att utveckla formella utbildningsinstitutioner och för att överföra teknik av ett slag som i sin tur fordrade att en kår av experter utbildades i eller för mottagarlandet. Denna distinktion innebär att begreppet utbildningsbistånd kan förstås i en bredare och en smalare mening. I bredare mening kan det avse alla former av utbildningsinsatser inom ramen för biståndsfinansierade utvecklingsprojekt. I den smalare meningen, som är den jag utgår från här, åsyftas mer specifikt projekt

5 Barnita Bagchi, Eckhardt Fuchs och Kate Rousmaniere, "Connecting Histories of Education: Transnational and Cross-Cultural Exchanges in (Post-)Colonial Education," i Connecting Histories of Education: Transnational and Cross-Cultural Exchanges in (Post-)Colonial Education, red. Barnita Bagchi, Eckhardt Fuchs och Kate Rousmaniere (New York: Berghahn Books, 2014), 1-2.

6 Detta anknyter i viss mån till de perspektiv som förordas av företrädare för den s.k. rumsliga vändningen i historisk forskning. För översikter av innebörden av denna, se t.ex. Erland Mårald och Christer Nordlund, "Förord," i Topos: Essäer om tänkvärda platser och platsbundna tankar, red. Erland Mårald och Christer Nordlund (Stockholm: Carlssons, 2006); Marie Cronqvist, "Spatialisera alltid! Rummets återkomst i de historiska vetenskaperna," Scandia 74, no. 2 (2010). Rumsliga perspektiv har även vunnit insteg bland utbildningshistoriker; se t.ex. ett specialnummer av History of Education: Catherine Burke, Peter Cunningham och Ian Grosvenor, red. "'Putting Education in Its Place': Space, Place and Materialities in the History of Education," History of Education 39, no. 6 (2010). Även fältets svenska företrädare har tagit upp dessa temata; se t.ex. Joakim Landahl, ”Det nordiska skolmötet som utbildningspolitisk arena (1870-1970): Ett rumsligt perspektiv på den moderna pedagogikens historia," Utbildning och demokrati 24, no. 3 (2015).

7 Stephen P. Heyneman och Bommi Lee, "International Organizations and the Future of Education Assistance," International Journal of Educational Development 48 (2016).

8 Walt Whitman Rostow, The Stages of Economic Growth: A Non-Communist Manifesto (Cambridge: Cambridge University Press, 1960), 4. För historiska översikter över detta slags tänkande, se t.ex. Francis X. Sutton, "Development Ideology: Its Emergence and Decline," Daedalus 118, no. 1; Michael Adas, Dominance by Design: Technological Imperatives and America's Civilizing Mission (Cambridge, 2006), kapitel 5; om utbildningsbistånd specifikt, se Richard Tabulawa, "International Aid Agencies, Learner-Centred Pedagogy and Political Democratisation: A Critique," Comparative Education 39, no. 1 (2003), 14-15. 
eller projektdelar med inriktning på att skapa eller stödja olika slags utbildningsinstitutioner i samarbetslandet.

Utbildningsbiståndet, i denna mening, har framförallt behandlats av den pedagogiska och utbildningsvetenskapliga forskningen. ${ }^{9}$ Det finns däremot enbart ett begränsat historiskt forskningsläge på området. Den utbildningshistoriska forskningen har inte särskilt uppmärksammat utbildningen i utvecklingsbiståndet, ens när den explicit har tematiserat gränsöverskridande möten. ${ }^{10}$ Däremot finns, internationellt men också i Sverige, en del historiska arbeten om internationaliseringen av akademisk utbildning som ibland också innefattar biståndsfinansierade initiativ. ${ }^{11}$ Den biståndshistoriska litteraturen inkluderar slutligen en del studier av utbildningsbistånd i olika former, men särskilt i Sverige är detta forskningsfält fortfarande begränsat. ${ }^{12}$ På det hela taget menar jag att vi fortfarande saknar kunskap om hur och varför svenska biståndsexperter och -administratörer har försökt bedriva utbildning för utveckling. Min studie av skogsutbildning och silvi-kulturella möten blir ett bidrag till att fylla denna lucka, och därmed samtidigt ett bidrag både till det utbildningshistoriska och till det biståndshistoriska fältet.

Distinktionen mellan det utbildningshistoriska och det biståndshistoriska aktualiserar också en skillnad av viss analytisk betydelse för min studie. Det projekt jag studerar var en del av SIDA:s bredare utvecklingssamarbete med Etiopien. Dess utformning och genomförande var dock kontrakterat till skogliga experter från SLU. Detta gav upphov till en viss spänning mellan å ena sidan SIDA:s biståndspolitiska mål och överväganden, och å andra sidan SLU:s prioriteringar. I botten, om än inte alltid diskuterat explicit, låg frågan om hur sambandet mellan akademisk skogsutbildning och fattigdomsbekämpning och allmän samhällsutveckling såg ut, eller om en tydlig sådan koppling överhuvudtaget fanns. Ur SLU:s perspektiv var sambandet närmast självklart när projektet inleddes. Även om engagemanget i etiopisk skogsutbildning ägde rum vid en tidpunkt då 1950- och 60-talens moderniseringsideologi hade ersatts av en bredare flora av utvecklingsteorier så fanns många av de underliggande föreställningarna om utveckling och modernitet som nära kopplat till bemästrandet av tekno-vetenskapliga resurser fortfarande kvar. ${ }^{13}$ Det var, till exempel, en

9 För svensk forskning inom denna tradition, se t.ex. Ann-Louise Bäcktorp, When the First-WorldNorth Goes Local: Education and Gender in Post-Revolution Laos (Umeå: Umeå universitet, 2007); Paula Mählck och Måns Fellesson, "Capacity-Building, Internationalisation or Postcolonial Education? Space and Place in Development-Aid-Funded PhD Training," L'Education Comparée 15 (2016).

10 Se t.ex. innehållet i den ovan citerade antologin: Bagchi, Fuchs och Rousmaniere (2014).

11 För Sverige vill jag särskilt framhålla Andreas Åkerlunds historiska studier av stipendiefinansiering av akademiska utbyten: Andreas Åkerlund, "The Impact of Foreign Policy on Educational Exchange: The Swedish State Scholarship Programme 1938-1990," Paedagogica Historica 50, no. 3 (2014); Andreas Åkerlund, "For Goodwill, Aid and Economic Growth: The Funding of Academic Exchange through the Swedish Institute, 1945-2010," Nordic Journal of Educational History 2, no. 1 (2015).

12 Mer finns skrivet i övriga Skandinavien; en bra startpunkt är de breda historiker som finns över norskt och danskt bistånd som syntetiserar tidigare studier, inklusive sådana med fokus på utbildningsprojekt: Christian Friis Bach et al., Idealer og realiteter: Dansk udviklingspolitiks historie 19452005 (Köpenhamn, 2008); Jarle Simensen et al., Norsk utviklingshjelps historie, 3 vol. (Bergen, 2003). För Sverige har jag i en tidigare studie analyserat ett tidigt utbildningsbiståndsprojekt: Karl Bruno, "Nils Lagerlöf och det tidiga svenska biståndet," Personhistorisk tidskrift 110, nos. 1-2 (2014).

13 För en idéhistorisk översikt över utvecklingsteori, se Bertil Odén, Biståndets idéhistoria: Från Marshallhjälp till milleniemål (Lund: Studentlitteratur, 2006). 
allmän uppfattning bland svenska skogsexperter som verkade i Etiopien vid denna tid att landet var drabbat av långt gången avskogning med åtföljande miljöproblem. För att stoppa avskogningen krävdes, menade de, rationella och vetenskapligt grundade insatser som emellertid starkt försvårades genom de rådande politiska, sociala och institutionella förhållandena i Etiopien. ${ }^{14}$ I ljuset av detta såg de utbildning som en nödvändig väg framåt för att stärka landets skogliga institutioner, vilket i sin tur ansågs vara en förutsättning för modern, rationell skogsskötsel.

På ett mer allmänt plan var detta sätt att tänka rotat i en fortsatt uppfattning om samhällsutveckling som en universell och stegvis process, och det var följaktligen naturligt för de svenska experterna att dra paralleller mellan Etiopiens samtida problem och Sveriges förflutna. ${ }^{15}$ Den svenska skogsskötselns självbild var och är baserad på en historieuppfattning i vilken ny lagstiftning och införandet av vetenskapligt grundade metoder för skogsskötseln blev centrala komponenter i den svenska landsbygdens utveckling under första hälften av 1900-talet, en utveckling som lyfte många människor ur fattigdom och bidrog till skapandet av det moderna, industrialiserade Sverige. ${ }^{16}$ Denna framgångssaga har, oaktat (eller kanske snarare tack vare) att den döljer både komplexitet och konflikter, fungerat som en grundläggande ideologisk premiss för svenskt skogsbruk. Den har också kommit att legitimera exporten av svenskt skogskunnande till övriga världen. ${ }^{17}$ Detta gjordes mycket explicit i den vision som landsbygdsminister Eskil Erlandsson lät ta fram 2011 under titeln Skogsriket - Med värden för världen. I denna sammanfattades vad som uppfattades som svenska skogsvärderingar, inte minst den balans mellan produktions- och miljömål som utmärker den nuvarande skogspolitiken. Planen uttryckte också, utan vidare problematisering, att Sverige skulle sprida kunskap globalt om den svenska modellen och om uthålligt skogsbruk. ${ }^{18}$ Det skogliga biståndsprojekt jag studerar ägde rum under årtiondena före formuleringen av visionerna om Skogsriket och hade mer begränsade anspråk, men det byggde på samma underliggande föreställning om ett särskilt svenskt skogskunnande, som med fördel skulle kunna spridas till länder med ett mindre utvecklat skogsbruk. I artikeln undersöker jag denna föreställning omsatt i praktik: vad hände när svenska skogsexperter förväntades utforma utbildningar och undervisa i nya miljöer? Vad utmärkte deras insatser, varför såg de ut som de gjorde, och hur togs de emot?

14 För ett exempel på en sådan analys, se Mårten Bendz, "Forests and Forestry in Ethiopia" (Växjö: Rural Development Consultants, 1988).

15 Särskilt den postkoloniala litteraturen har påpekat hur denna utvecklingssyn kom att leva kvar även efter att moderniseringsteorier (i vid mening) förlorade mycket av sin trovärdighet. Se t.ex. Maria Eriksson Baaz, "Biståndet och partnerskapets problematik", i Sverige och de Andra: Postkoloniala perspektiv, red. Michael Mc Eachrane och Louis Faye (Stockholm, 2001), 168-72.

16 För en skogshistorisk översikt, se Einar Stridsberg och Leif Mattsson, Skogen genom tiderna: Dess roll för lantbruket från forntid till nutid (Stockholm: LT, 1980). Den högre skogliga utbildningens roll har knappast uppmärksammats av forskningen. Skoglig yrkesutbildning (under efterkrigstiden) har dock analyserats av Fay Lundh Nilsson, "De specialiserade yrkesutbildningarna: Exemplet skoglig utbildning," i Yrkesutbildningens formering i Sverige 1940-1975, red. Peter Håkansson och Anders Nilsson (Lund: Nordic Academic Press, 2013).

17 Se t.ex. Reidar Persson, Assistance to Forestry: Experiences and Potential for Improvement (Jakarta: Center for International Forestry Research, 2003), 30-32.

18 Skogsrikets värderingar och ideologier analyseras i Sara Holmgren och Seema Arora-Jonsson, ”The Forest Kingdom - With What Values for the World? Climate Change and Gender Equality in a Contested Forest Policy Context," Scandinavian Journal of Forest Research 30, no. 3 (2015). 
Några svar på dessa frågor finns inte i tidigare forskningslitteratur. Det som finns skrivet om SLU:s engagemang i etiopisk skogsutbildning har till sin absoluta huvuddel författats av personer som själva har varit delaktiga, och det mesta har karaktär av översikter och summeringar som inte mer än ytligt kan bidra till mina frågeställningar. ${ }^{19}$ Jag bygger därför framställningen i huvudsak på otryckt källmaterial från SLU:s samt de svenska biståndsmyndigheternas arkiv. Jag har också intervjuat flera av de inblandade svenska experterna.

\section{Möte I: Svensk silvi-kultur}

Svenskt skogligt bistånd till Etiopien inleddes under 1960-talet och växte i omfattning efter revolutionen 1974, då SIDA inledde ett brett skogligt samarbete med landet. Av särskild vikt i detta sammanhang är det stöd till utbildning och träning som inleddes 1978 med kurser för skogstekniker vid det nyskapade Wondo Genet Forestry Resources Institute utanför staden Shashemene, i ett område som fortfarande hade en del äldre skog. Utbildningen vid Wondo Genet ledde inte till någon akademisk examen utan var en diplomautbildning med starkt praktisk inriktning. Stödet till institutet administrerades inte av SLU utan, till en början, av ett konsortium bestående av två svenska konsultföretag, ORGUT och SwedForest. Efter 1986 tog SIDA självt över det operativa ansvaret. ${ }^{20}$

Eleverna som utbildades vid Wondo Genet kunde sköta kvalificerade uppgifter i det praktiska skogsbruket, men fann det svårt att gå vidare till administrativa eller arbetsledande tjänster på högre nivå. Den diplomaexamen de fick öppnade heller inte för vidare akademiska studier. ${ }^{21}$ De svenska biståndsexperterna ansåg att detta var otillfredsställande i ljuset av deras starka uppfattning att fler experter behövdes i Etiopiens skogliga förvaltning. En i detta avseende särskilt tongivande aktör var Sven-Gunnar Larsson, rektor för Skogsmästarskolan i Skinnskatteberg, som var en del av SLU. I mitten av 1980-talet var Larsson tjänstledig och verkade istället på en SIDA-finansierad tjänst för arbetskraftsfrågor vid Natural Resources Conservation Development, Main Department, den avdelning av det etiopiska jordbruksministeriet som bland annat sysslade med skogsärenden. Larsson hade stort inflytande på sin etiopiska motpart och fungerade enligt ett internt SIDA-PM i praktiken som koordinator för hela det skogliga biståndsprogrammet. ${ }^{22}$ Under 1985 och 1986 genomdrev han, med benäget stöd från bland annat SLU:s tidigare rektor Lennart Hjelm och universitetets förvaltningschef Görel Oscarsson, att diplomaprogrammet vid Won-

19 Sven-Olov Bylund, "Lämnar Wondo Genet efter 30 år," Resurs, no. 3 (2009); Gessesse Dessie och Menfese Tadesse, "Rethinking Forestry and Natural Resources Higher Education in Ethiopia: An Education for Sustainable Development Perspective," Southern African Journal of Environmental Education 29 (2012/2013); Björn Lundgren, Reidar Persson, och Sten Norén, "Swedish-African Forest Relations," Kungl. Skogs- och Lantbruksakademiens tidskrift 150, no. 2 (2011); Mats Sandewall, "Skoglig utbildningssatsning i Etiopien - Vad blev utfallet?" Fakta skog - Rön från Sveriges lantbruksuniversitet, no. 9 (2014); Johan Toborn, "SLU och etiopisk skogsutbildning: En fråga om att lära eller läras," Skog och forskning 96, no. 1 (1996); Johan Toborn, "Etiopien: 'ett SLU-land”' i Sammanhang: SLU 25 år, red. Gunilla Ramberg (Uppsala: Sveriges lantbruksuniversitet, 2002).

20 Sven Sjunnesson, intervju av författaren, 29 januari 2015 (inspelning i författarens ägo).

21 Ibid.

22 Lars Sandahl, "PM om Sven-Gunnar Larsson, Manpower Development Coordinator, Natural Resources Conservation Development Main Department (NRCDMD), Ministry of Agriculture, Etiopien," 6 december 1985, SIDA:s centralarkiv, F1 AD: 2983, Riksarkivet (nedan SIDA). 
do Genet skulle kompletteras med en SIDA-finansierad och av SLU administrerad akademisk påbyggnadsutbildning upp till kandidatnivå, eller ungefär motsvarande den svenska skogsmästarutbildningen. SLU utformade därefter en utbildning på två och ett halvt år, med fyra terminer i Wondo Genet och en termin vid Skogsmästarskolan i Skinnskatteberg. ${ }^{23}$ Den avsågs inte bli permanent, utan planerades för tre kurser: en från 1986-1988, en andra från 1987-1989, och en sista från 1988-1990. Totalt sett planerades programmet omfatta omkring femtio etiopiska studenter.

De första studenterna inledde sina studier vid Wondo Genet på hösten 1986. Kursprogrammet bestod till en början av inledande studier i ett antal av de skogliga ämnena samt i engelska språket. Skogsundervisningen sköttes främst av utstationerade lärare från SLU och fokuserade på skogsskötsel, skogs- och träteknik, och skogstaxering. ${ }^{24}$ Med den tredje terminen, som var förlagd till Sverige, inträdde sedan en viktig pedagogisk förändring. Den huvudsakliga målsättningen med Sverigeterminen var att låta studenterna uppleva skogsbruk under helt andra förhållanden än de som rådde i Etiopien, eller, som Sven-Gunnar Larsson själv uttryckte sig i en delrapport om utbildningen, att låta "the students take part of and live in a society and an envirionment [sic] where forestry plays such an important role, and to have an easy and natural access to educational and learning resources [...]." ${ }^{25}$

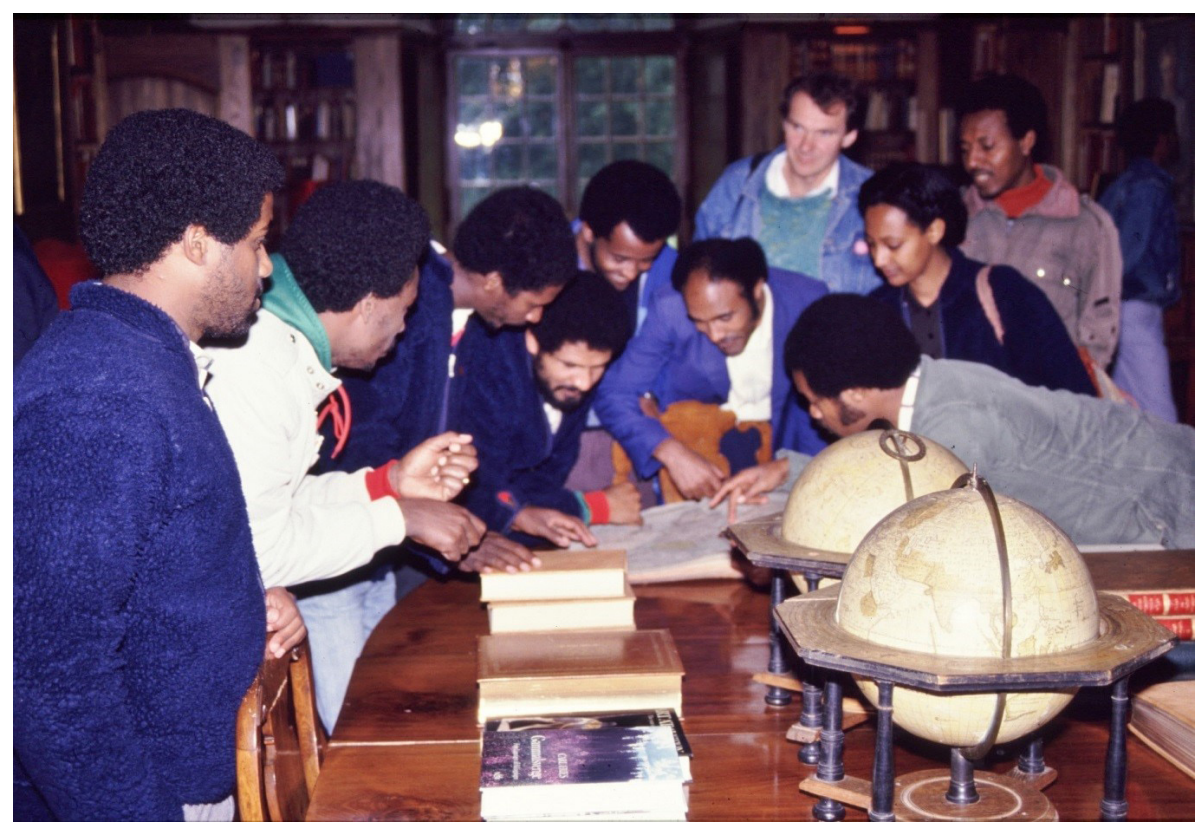

Figur 1. Etiopiska studenter besöker biblioteket vid Adelsnäs gods utanför Åtvidaberg under överinseende av Torgny Söderman från SLU. Adelsnäs utgjorde (och utgör) centrum för Baroniet Adelswärd $\mathrm{AB}$, ett stort jordbruksföretag vars skogliga verksamhet helt saknade motsvarighet i Etiopien, och besöket är ett bra exempel på det slags studieresor som ingick i Sverigeterminen. Foto: Sven Sjunnesson, 1987.

23 Se kontraktet mellan SIDA och SLU gällande Bachelor of Science, Forestry Management, Appendix B, 26 september 1986, SIDA, F1 AD: 2984.

24 För en översikt av kursstrukturen, se det ovan citerade kontraktet mellan SIDA och SLU, Annex I.

25 Sven-Gunnar Larsson, "BSc Forestry Management Training Project: Progress Report no. 3," 2, SIDA, F1 AD: 5209. 
En viktig del av terminen var följaktligen studieresor genom vilka studenterna fick bekanta sig med skogsföretag och försöksplanteringar i olika delar av Mellansverige. ${ }^{26}$ Men även den mer direkta undervisningen fick en annan karaktär. När Larsson skrev om naturlig tillgång till läranderesurser syftade han på enkel tillgång till stora skogsområden för praktisk utbildning. Över en tredjedel av de lärarledda studierna under Skinnskattebergsterminen bestod av tillämpade övningar i fält, som integrerade de olika skogliga ämnena som studenterna tidigare hade läst. Under en av kurserna ägnades exempelvis en stor del av tiden åt "an integrated exercise in silviculture, operational planning and ergonomics. In this practical thinning-exercise all operations were fulfilled by the students themselves: Planning, selection of trees, felling operations, time studies, ergonomic studies and a final follow-up of the results." ${ }^{27}$ Sådana övningar var viktiga i de flesta ämnena, och under terminen i Sverige lade SLU:s lärare också i allmänhet stor vikt vid att komplettera den tidigare huvudsakligen teoretiska undervisningen med praktisk träning. ${ }^{28}$

För de etiopiska studenterna innebar Sverigeterminen inte bara ett möte med en ny skoglig miljö utan också med en politisk miljö som skilde sig dramatiskt från den brutala polisstat de kom från. Tre av studenterna från den första kursen ansökte om politisk asyl i Sverige, och fyra av deras efterföljare under kurs nummer två gjorde samma sak. Det etiopiska jordbruksministeriet, SIDA:s samarbetspartner, var inte överdrivet upprört över detta, men ur SIDA:s perspektiv underminerade avhoppen projektets syfte, och biståndskontoret i Addis Abeba lyfte möjligheten att stryka Sverigeterminen från den tredje och sista kursen för att undvika att fler studenter lämnade utbildningen. I och med detta framträder en tydlig åtskillnad mellan SLU:s och SIDA:s mål, där den senare myndigheten vägleddes av biståndspolitiska överväganden som skar sig mot den förras uppfattning om pedagogiska nödvändigheter. SLU:s utbildningsplanerare reagerade skarpt mot förslaget att ta bort terminen i Skinnskatteberg, och framhöll att detta skulle få allvarliga konsekvenser för utbildningen. ${ }^{29}$ Ett PM av Per Rudebjer, kursansvarig i Sverige, skissade dessa. ${ }^{30}$ Det mest problematiska, ur SLU:s perspektiv, var att utbildningsprogrammet var upplagt kring den pedagogiska tanken att använda den tredje terminen till att arbeta integrerat med olika ämnen i en kontext där det både fanns mycket skog och ett starkt industriellt skogsbruk. Denna idé skulle undermineras om terminen flyttades till Etiopien, där förhållandena för praktiska övningar också var betydligt sämre. Samma poäng hade även gjorts tidigare, i samband med en utvärdering av den första studentgruppens Sverigetermin. Rudebjer och lärarna Lars Höök och Gustav Fredriksson hade då framhållit att utan Sverigeterminen skulle "[t]he practical touch of the training" försvagas betydligt, och sammantaget skulle det inte vara möjligt att bibehålla utbildningens kvalitet utan en termin i Sverige. ${ }^{31}$

26 Per Rudebjer, Lars Höök och Gustav Fredriksson, "An Evaluation of the Third Semester in Sweden," 3, 30 november 1987, SIDA-ETI, F72: 21.

27 Ibid., 5.

28 Ibid., 3.

29 Sven-Gunnar Larsson till Lars Leander, 8 november 1988, SIDA-ETI, F72: 21.

30 Per Rudebjer, "What Does it Mean to Locate Semester 3 to Ethiopia?" 1, 18 oktober 1988, SIDA-ETI, F72: 21 .

31 Rudebjer, Höök och Fredriksson, "An Evaluation of the Third Semester," 9. 
Till slut kom terminen också att kvarstå i Skinnskatteberg. ${ }^{32}$ Detaljerna i det beslutet är i detta sammanhang mindre intressanta än de reaktioner frågan framkallade hos SLU:s experter. De utgör ett första exempel på hur den integrerade och praktiskt orienterade svenska modellen för högre skoglig utbildning problematiserade och problematiserades av etiopiska silvi-kulturella förhållanden (och samtidigt riskerade att hamna i konflikt med biståndets mer politiska överväganden). Här fanns en tydlig paradox. SLU framhöll gärna att kursen var skräddarsydd för etiopiska förhållanden, men hade samtidigt valt att utforma den på ett sätt som krävde en termins studier i Sverige. En mer generell silvi-kulturell fråga blir därmed svår att undvika: i vilken utsträckning var mötet med svenskt skogsbruk verkligen relevant för utbildningen av en etiopisk skogsmästare som skulle verka i Etiopien?

Det finns ett fătal etiopiska röster i det källmaterial jag har använt. Ett exempel är en skildring av resan till Sverige av kursdeltagaren Taye Bekele, skriven för den examenstidning som gjordes i samband med att kurs nummer tre tog sin examen $\mathrm{i}$ juni 1990. ${ }^{33}$ Taye noterade förvisso att praktiska erfarenheter var en av resans höjdpunkter, men till skillnad från de andra, ganska tekniskt hållna artiklarna i tidningen, diskuterade han inte utbildningens innehåll eller upplägg i någon detalj. Detta är bara ett löst indicium, men skulle kunna antyda att det var svårt för studenterna att avgöra vilka tillämpningar Sverigeterminen hade. Vidare gjorde den första studentgruppen en kursutvärdering, där studenterna direkt gav uttryck för sin uppfattning om Sverigeterminen. Omdömena var positiva men inte översvallande: kursledningens sammanfattning lyder enbart " $\mathrm{t}]$ he training is possible to apply to ethiopian [sic] conditions." ${ }^{34}$ Eftersom detta omdöme är filtrerat genom SLU:s lärare är det omöjligt att avgöra vad studenterna faktiskt tyckte eller i vilken utsträckning de upplevde sig fria att ge uttryck för sina uppfattningar. Formuleringen antyder dock en ganska begränsad entusiasm för terminens praktiska relevans. Om inte annat är det troligt att kursledningen, som ju värnade starkt om Sverigeterminen, hade uttryckt sig mer översvallande om omdömena hade varit samstämmigt positiva och studenterna utan vidare ansåg kunskaperna tillämpbara i Etiopien.

De som planerade kursen vid SLU var själva medvetna om att Sverigeterminens relevans kunde vara ett problem. Vid ett stort planeringsmöte sommaren 1986 hade fördelar och nackdelar med studier i Sverige diskuterats, och i mötesprotokollet noterades att det fanns en "viss risk att [studenterna] lär sig tekniker mindre väl anpassade för etiopiska förhållanden". ${ }^{35}$ Samtidigt identifierade man dock ett antal argument för en Sverigetermin, där det viktigaste var att Sverige hade ett holistiskt och systemiskt tänkande kring skogsbruket som saknades i de flesta andra länder, och att de etiopiska studenterna skulle gynnas av att komma i kontakt med detta sätt att tänka om skog. Denna föreställning - sann eller falsk - om det speciella svenska skogsbruket blev en avgörande ideologisk utgångspunkt som fick direkt genomslag i hur Sverigeterminen, med sina många studiebesök och integrerade övningar, utformades. Med andra ord syftade terminen ytterst till att utförligt demonstrera den

32 Mötesprotokoll, linjenämnden för kandidatprogrammet, 12 maj 1989, SIDA, F1 AD: 2988.

33 Taye Bekele, "A Journey to the Land of the Midnight Sun, Sweden", i "Graduation Day Magazine: Batch III, Bachelor of Science, Forestry Management," maj 1990, SIDA, F1 AD: 2989.

34 Larsson, "BSc Forestry Management Training Project: Progress report no. 3," 5.

35 Sten Norén, "Möte om skogsutbildning i Etiopien," 2, 18 juni 1986, SIDA, F1 AD: 2984. 
svenska silvi-kulturen för de etiopiska studenterna. Planerarna vid SLU - och denna punkt ifrågasattes inte i sig av SIDA vid denna tid - förefaller ha varit övertygade om att detta skulle gynna etiopiskt skogsbruk på längre sikt, även om det inte ledde till några omedelbara utvecklingseffekter. Det är också tydligt att de svenska experterna var övertygade om nödvändigheten och nyttan av en praktisk skogsutbildning också på plats i Etiopien, vilket blir tydligt i min analys av nästa silvi-kulturella möte.

\section{Möte II: Praktisk silvi-kultur}

Samtidigt som man under slutet av 1980-talet gav kandidatutbildningen till tre grupper av etiopiska studenter var SLU också engagerat i att planera ett mer omfattande institutionellt samarbete med Alemaya lantbruksuniversitet (Alemaya University of Agriculture, AUA) i östra Etiopien, där en ny skogsfakultet var på väg att bildas. En central del i planeringen var att ta fram en ny utbildningsplan för en permanent skoglig kandidatutbildning vid Alemaya. Detta arbete skilde sig på viktiga punkter från den mer tillfälliga kandidatutbildningen som gavs vid Wondo Genet och i Sverige. Målgruppen för den senare var studenter som redan hade en skoglig utbildning på lägre nivå. AUA, å andra sidan, var ett universitet under det etiopiska utbildningsministeriet vars enda inträdeskrav var avslutad sekundärutbildning på motsvarande gymnasienivå. Det låg också i en del av landet där de naturliga förhållandena var mycket annorlunda än i Wondo Genet, nämligen i en avskogad del av Harrargheprovinsen där ett arboretum erbjöd de enda möjligheterna till praktisk utbildning.

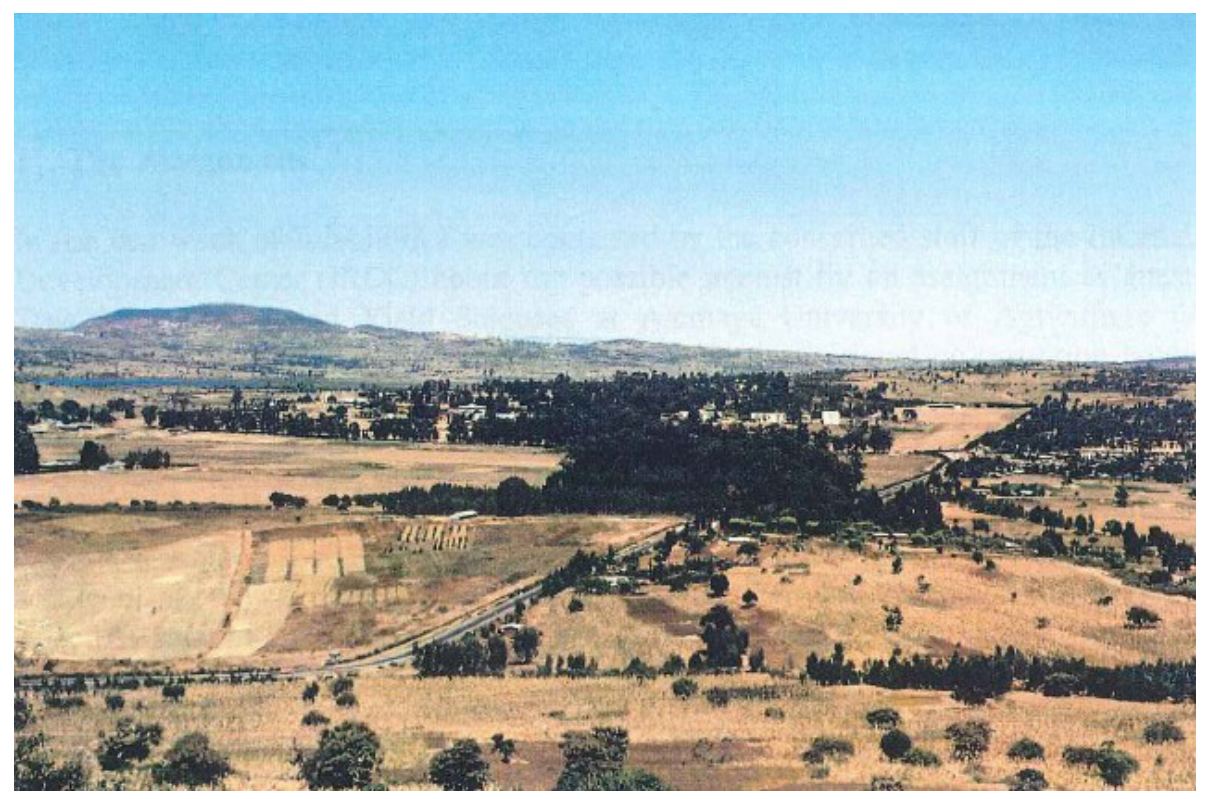

Figur 2. Alemaya lantbruksuniversitet omgivet av jordbruksmark. Arboretet i bildens mitt gav den enda möjligheten till praktiska övningar på plats. Foto Mats Sandewall, årtal okänt.

Redan från början hade SLU:s experter uttryckt viss tveksamhet när det gällde möjligheten att bedriva skoglig utbildning vid AUA. På ett tidigt stadium ifrågasatte man till exempel om "forests for the students' exercises existed at acceptable distance 
from Alemaya, both natural and man-made forests". ${ }^{36}$ Detta förhållande, som skilde sig från Wondo Genet där det fanns både planteringar och naturskog på och i anslutning till skolan, gjorde det avsevärt mycket svårare att bygga upp en utbildning med ett stort inslag av praktiska övningar. För AUA:s huvudman, det etiopiska utbildningsministeriet, var detta inget problem. Ministeriet hade redan tagit fram en egen utbildningsplan som saknade praktik och vars två första år lästes tillsammans med agronomstudenterna. ${ }^{37}$ Här fanns således två motsatta uppfattningar om vad akademisk skogsutbildning kunde och borde vara. För de svenska experterna var praktisk, skogsbaserad träning en oundgänglig del av en sådan, medan de etiopiska utbildningsplanerarna kunde tänka sig ett helt teoretiskt utbildningsprogram.

I en senare analys av möjligheterna för SLU att samverka med Alemayauniversitet utvecklade en grupp experter, som inkluderade skogsfakultetens dekanus Per-Ove Bäckström, de svenska synpunkterna. Möjligheterna till praktisk träning utgjorde en central spänningspunkt för experterna, som explicit tog sin utgångspunkt i det svenska utbildningssystemet. De beskrev praktiken som "vital" för den svenska jägmästarlinjen (som beskrevs som den närmaste motsvarigheten till det kandidatprogram som skulle startas vid Alemaya), och framhöll hur denna utbildning inleddes med fyra och en halv månads inledande yrkesanknutna studier både vid en skogsskola och ett skogsföretag och hur de följande två årens grundläggande kurser både innehöll studieresor och mycket träning i skogsområden. ${ }^{38}$ Efter att på detta sätt ha presenterat det svenska systemet fortsatte Bäckström och hans två kolleger med att jämföra den SLU-ledda kandidatutbildningen i Wondo Genet/Skinnskatteberg med det förslag på en ny utbildning vid Alemaya som jordbruksministeriet hade tagit fram. De började med den allmänna synpunkten att en betydande skillnad mellan de två var att det fanns en "emphasis on practical training in the [SLU] program", som dessutom riktade sig till studenter som redan hade en grundläggande och huvudsakligen praktisk skoglig utbildning. ${ }^{39}$ Det var inte "immediately evident" från det liggande förslaget att jordbruksministeriet hade insett vikten av detta. En annan viktig skillnad var att SLU:s kandidatprogram starkt betonade vikten av att integrera de olika skogliga ämnena, något som man särskilt ägnade sig åt under terminen i Sverige. Detta var, erkände rapporten, svårt att åstadkomma på ett fullt tillfredsställande sätt i Etiopien. Författarna ansåg likväl att både praktik och integration var nödvändigt för att möta behoven hos studenternas framtida arbetsgivare, som framförallt antogs vara jordbruksministeriet självt. ${ }^{40}$

Dessa uppfattningar kom också att slå igenom när en plan för SLU:s stöd till Alemaya senare färdigställdes inför samarbetets planerade start 1989. I planen gavs stort utrymme till en diskussion av nyttan av praktisk träning för skogsmän och -kvinnor:

36 "Draft Agreed Minutes of the 1987 Annual Review on Forestry," appendix 2, 30 april 1987, SIDA-ETI, F72: 16.

37 Se Alf Arvidsson, Lars Höök, Göran Peterson och Folke Bohlin, "Förslag till insatser vid uppbyggandet av en skoglig fakultet vid det etiopiska lantbruksuniversitetet i Alemaya," bilaga 5, 2, 26 mars 1986, SIDA-ETI, F72: 16.

38 Per-Ove Bäckström, Johan Toborn och Marianne Wibom, "SUAS Forestry Mission to Ethiopia: B.Sc. Forestry Training at Wondo Genet; Forestry Training at the Agricultural University of Alemaya (AUA); Prospects for Cooperation between AUA and SUAS; Final Report" (Uppsala: Sveriges lantbruksuniversitet, 1988), 18.

39 Ibid., 29

40 Ibid., 29-30. 
In recent years it has become generally accepted that Ethiopian university studies in natural sciences are deficient in terms of practical training. For agricultural students this is verified by the practical training now given to the students during one of the otherwise summer holidays. The SUAS B.Sc. forestry management training [kandidatprogrammet i Wondo Genet/Skinnskatteberg] constitutes an interesting alternative to the AUA B.Sc. training as once suggested. According to the SUAS model, students are to have passed the diploma training at Wondo Genet where much practice is included, work for a couple of years, and only then take up B.Sc. studies where again much practical training is comprised. In view of the experiences, the original AUA curriculum was therefore made to accommodate the request for more practicals [...]. ${ }^{41}$

Men det var alltså problematiskt att bedriva den typ av praktisk utbildning som SLU:s experter ansåg vara central, i Etiopien i allmänhet men i Alemaya med omnejd i synnerhet. Under rubriken "Practical B.Sc. Training" diskuterade planens författare detta:

B.Sc. training in forestry cannot be confined to Harrarghe only. The limited representativeness of ecological conditions and the poor access to forests of different characters make impossible [sic] to retain all practical training in the region. As a first approximation the practical and theoretical parts of the courses in the curriculum [...] are located to suitable areas. ${ }^{42}$

I detta avseende reflekterade planen tydligt SLU:s experters idéer om vad skoglig utbildning innebar. Dessa var noga med att framhålla att de grundade sina resonemang på tidigare erfarenheter från Etiopien och att de innebar en anpassning av utbildningen till etiopiska förhållanden och därmed förknippade behov av expertis. Men att så faktiskt var fallet var inte självklart, vilket framgår av en intervju med AUA:s skogsdekanus Badege Bishaw. Badege, som formellt var medförfattare till den ovan citerade planen men som uppenbarligen inte hade fått gehör för sitt synsätt, instämde i att förhållandena i Harrarghe-provinsen gjorde det svårt att få till stånd praktik, men menade ändå att Alemaya var en lämplig plats för högre skoglig utbildning. Han argumenterade att det i ljuset av det hårda trycket på mark var osannolikt att Etiopien skulle återfå större skogsområden under överskådlig tid, och att landet därför behövde en typ av skogsexperter som kunde arbeta i nära samverkan med bönder och jordbruksrådgivning. Det innebar att det var en fördel att utbilda skogsmän på samma plats som agronomer, och att behovet av praktisk erfarenhet av storskaligt skogsbruk minskade. ${ }^{43}$

Att Badege inte fick stöd för sina idéer reflekterar åtminstone till viss del att hans svenska motparter, som genom biståndskontexten fick det större inflytandet, fortfarande utgick från en svensk förförståelse där akademisk skogsutbildning var tätt knuten till skoglig praktik och därmed till skogen som en konkret, fysisk plats. De förespråkade att också skogsutbildningen i Etiopien borde bygga på denna modell, trots att förhållandena där var så annorlunda från Sverige att detta ledde till svåra,

41 "Plans of Operations: The Forestry Faculty of the Alemaya Universiy of Agriculture (B.Sc. Training, Research, Extension, and Regular M.Sc. and Ph.D programmes); The Initial M.Sc. Programme and Ph.D. Programme in Forestry," 7, 22 december 1988, SIDA, F1 AD: 2987.

42 Ibid., 13.

43 Karin Fahlström, "Etiopiens förste skogsdekanus," U-landsskogisen 17 (1989), 8. 
delvis oöverkomliga problem. I praktiken gick man ganska långt i att anpassa omständigheterna till kursplanen istället för kursplanen till omständigheterna, till exempel genom att föreslå att stora delar av den praktiska utbildningen skulle förläggas till andra delar av Etiopien, något som även under bästa tänkbara omständigheter skulle innebära stora logistiska svårigheter ${ }^{44}$ På ett plan kan man förvisso betrakta detta som berömvärt: SLU:s experter stod fast vid vad de uppfattade som den enda hållbara lösningen på ett utvecklingsproblem och var redo att gå mycket långt för att göra denna lösning möjlig att genomföra. Det finns ingen anledning att betvivla att de förespråkade en svensk utbildningsmodell eftersom de var övertygade om nödvändigheten i att påvisa praktikens dygder för en ny generation etiopiska skogsexperter. Men samtidigt går det inte att undvika slutsatsen att detta försök att tillämpa den svenska modellen på en ny plats ledde till besvärliga komplikationer. Det var svårt att passa in den svenska förförståelsen i en ny silvi-kulturell miljö, men det är också tydligt att viljan till anpassning hade sina gränser. Etiopiska politiska förhållanden dikterade skogsfakultetens lokalisering till Alemaya, men de svenska experterna var påtagligt ovilliga att göra mer genomgripande anpassningar av sina utbildningsmodeller till de förhållanden som rådde där. De lyckades således inte bemästra den alltmer påtagliga inkongruensen mellan den silvi-kultur de representerade, och de omständigheter som de mötte i Etiopien.

\section{Möte III: Akademisk silvi-kultur}

Samarbetet mellan SLU och Alemaya kunde inte starta som avsett 1989, eftersom Sverige ändrade sin biståndspolitik gentemot Etiopien under slutfasen av det dåvarande inbördeskriget. Efter krigets slut återupptogs det svenska biståndet och SLU kunde återvända. De silvi-kulturella spänningarna kvarstod emellertid, som jag visade med den anekdot som inleder föreliggande artikel. Studenterna på den nya masterutbildningen ogillade kursplanens praktiska inslag och var missnöjda med att SLU hade anställt vissa lärare på basis av skoglig erfarenhet snarare än formella akademiska kvalifikationer. Detta reflekterade djupare problem kring klass, utbildning och expertidentitet där den svenska silvi-kulturen tydligt ställdes mot starka uppfattningar i Etiopien. För de svenska lärarna fanns ingen motsättning mellan att vara en högt utbildad expert och att delta i praktiskt, kroppsligt arbete, och inte heller - åtminstone inte i denna kontext - något problem med undervisning på basis av yrkeskunnande snarare än formella kvalifikationer. Men i Etiopien, liksom i många andra utvecklingsländer, fanns här en tydlig klassmarkör och skiljelinje, där den som var antagen till och i ännu högre grad utexaminerad från en högre utbildning inte kunde förväntas arbeta fysiskt på det sätt som de svenska experterna fordrade. Redan innan SLU kom in i bilden hade svenska lärare vid Wondo Genet mött, och frustrerats av, denna attityd. 1983 menade jägmästaren Anders Dahlqvist, som då undervisade där, att en stor del av undervisningen fick ägnas åt att försöka ändra studenternas uppfattning till att arbeta med händerna. ${ }^{45}$

Trots sådana insatser kvarstod alltså en spänning kring praktikens roll i akademisk utbildning, och den kom att fortsätta prägla projektet. Efter inbördeskriget

44 "Plans of Operations," 13.

45 Anders Dahlqvist, "Skogslärare i Etiopien: Ilska, glädje, men aldrig tråkigt," U-landsskogisen 11 (1983), 10-11. 
började SLU, utöver det masterprogram man ordnade, till slut att ge stöd till den nya etiopiska skogsutbildningen vid Alemaya, men vid ett seminarium om metodutveckling 1993 noterade SLU:s representanter att de svenska och etiopiska deltagarna stod långt ifrån varandra i frågan om kursplanernas utveckling, något som med stor sannolikhet syftade på det återkommande problemet att erbjuda den praktiska träning SLU såg som nödvändig i området kring Alemaya. ${ }^{46}$ Studenterna togs på studieresor till Wondo Genet och Munessaskogen, men de svenska experterna ansåg att dessa resor närmast fick sightseeingkaraktär. De kunde inte ersätta behovet av gedigen praktik i anslutning till utbildningens förläggningsort. ${ }^{47}$

I ljuset av detta är det förståeligt att SLU:s projektansvariga och personal i Etiopien ställde sig mycket positiva när de etiopiska myndigheterna i mitten av 1990-talet beslutade att all akademisk skogsutbildning skulle flyttas till skolan i Wondo Genet, som då gick under namnet Wondo Genet College of Forestry, och att samtidigt ge denna status som universitetsfakultet. ${ }^{48}$ Det visade sig dock snabbt att den nya miljön inte skulle komma att ingjuta en känsla för praktikens värde i den akademiska skogsutbildningen. Akademiseringen av skogsskolan i Wondo Genet ledde istället till en markant försvagning av den praktiska utbildningen där, och till en allt mer eftersatt skötsel av skolans egna skogsresurser. Den svenske jägmästaren Birger Hjelm, som tjänstgjorde vid Wondo Genet från maj 1999 till april 2001, rapporterade efter avslutad anställning att det inte fanns någon tvekan om att den akademiska nivån hade höjts och att detta i och för sig var positivt. Men akademiseringen medförde också betydande problem, vilka Hjelm sedan beskrev ganska ingående:

\begin{abstract}
However, at the same time we can see that practical oriented education has declined at the college. Students in all levels get little or no proper practical training in forestry subjects. Many colleagues confirmed that previously (about 10 to 15 years ago) students where given more practical exercises and participated directly in forestry operations at the college. The decline in forestry operations has resulted in miss-managed forest plantations and, consequently, there are few demonstration plots showing sound management and most of the research trial are abandoned. Due to lack of management, there is also a continuously great loss of economical value since the resources isn't utilized in a proper way. As stated above, academic improvement can be a development factor, but not on the expense on neglecting practical activities which is the whole base for the College. The objective to establish improved academic level is, in my opinion, to ensure improved management, utilization and sustainable development on the natural resources. I must be honest and say that I didn't see much of this connection at the college. ${ }^{49}$
\end{abstract}

Hjelm betraktade det som särskilt problematiskt att akademiseringen hade fătt negativa konsekvenser för skötseln av Wondo Genets skogar, och poängterade att ett så-

46 "Annual Report 1993/94: Management of Natural Resources in Ethiopia; SIDA Support through the Swedish University of Agricultural Sciences (SUAS)," 7, SIDA, F1 AD: 2992.

47 "Draft Plan of Operations, 1996/97, Forestry Faculty, Alemaya University of Agriculture," mars 1996. SIDA-ETI, F72: 35.

48 Daag Skoog till Lars Peter Herthelius (telefax), "Relocating the Forestry Faculty from Alemaya to Wondo Genet," 5 november 1995, SIDA-ETI, F72: 35; "Report from MSc Coordinator/Liaison Officer for the Period 1996-07-01 to 1997-02-20," 10, SIDA-ETI, F72: 35."

49 Birger Hjelm, "Final Report at Wondo Genet College of Forestry in Ethiopia," 6. Sidas arkiv, mapp NATUR 1999-2236, Sidas huvudkontor (nedan Sida). Citatet är exakt återgivet. 
dant nödvändigt verktyg som en skötselplan hade saknats under större delen av den tid han arbetade där. Ironiskt nog hade SLU bidragit till detta genom ett omfattande program som gav många av Wondo Genets etiopiska lärare möjlighet till forskarutbildning i Sverige. Hjelm noterade sarkastiskt att en anledning till att skogsskötselplanen saknades var att de som var ansvariga för att ta fram den istället ägnade sig åt att förbereda sina kommande doktorandstudier. ${ }^{50}$

Hjelms kritik delades av Sven Sjunnesson, som hade varit dekanus för studieärenden (Dean of Academic Affairs) vid Wondo Genet under sent 1980-tal. Under ett återbesök år 2000 upprördes han över vad han uppfattade som vanskötsel av skolan och dess skog. I sin reseberättelse beskrev han hur den lokala naturskogen, tidigare skyddad av skolan, nu förhärjades av lokala bönder som behövde betesmark och bränsle. Han skildrade också hur skolans egna skogsplanteringar och övningsområden inte längre sköttes utan fick förfalla. När det gällde konflikten med lokalbefolkningen kring tillgång till skogen handlade det inte i första hand om den interna utvecklingen på Wondo Genet utan, som Sjunnesson också framhöll i sin skildring, om den politiska utvecklingen i landet. Ett ökat regionalt självstyre hade minskat skolans manöverutrymme, eftersom de nya regionala myndigheterna tenderade att stödja de lokala bönderna i eventuella konflikter över tillgången till naturresurser resurser som oftast också var helt nödvändiga för deras försörjning. ${ }^{51}$

Med utvecklingen av skogsplanteringarna och övningsområdena ansåg både Sjunnesson och Hjelm det vara en annan sak. De menade bägge två att den var direkt kopplad till den allmänt förändrade inriktningen på skolan efter dess upphöjelse till fakultet. Sjunnesson, som menade att ett av Wondo Genets "särdrag" var praktiken, tyckte sig se att den nu "till stora delar" hade försvunnit eftersom undervisningen hade "akademiserats". ${ }^{52}$ Hjelm delade denna uppfattning och rapporterade att en vanlig attityd bland de etiopiska lärarna var att de praktiska övningar som trots allt förekom kunde skötas av underordnade assistenter. Han menade, helt i linje med vad SLU:s experter hade förespråkat sedan mitten av 1980-talet, att det var nödvändigt att den praktiska undervisningen uppvärderades och att fler fältförlagda övningar infördes, under ledning av den akademiska personalen..$^{53}$ Allt detta var förstås djupt ironiskt, för om det fanns ett dominerande drag i SLU:s arbete med att utveckla den etiopiska skogsutbildningen så var det just det återkommande försöket att förmedla en bild av akademisk skogsutbildning som något som byggde på en syntes av teori och praktik. Man hade emellertid inte lyckats bryta ner gränsen mellan högre utbildning och praktiskt arbete, och därmed blev en konsekvens av Wondo Genets akademisering att praktiken betonades allt mindre.

Efter flytten av all etiopisk högre skogsutbildning till Wondo Genet uppstod också en ny spänning mellan SLU och Sida, ${ }^{54}$ där biståndspolitiska mål om fattigdomsbekämpning och lokalt deltagande kom i viss konflikt med SLU:s kompetenser inom

50 Ibid.

51 Sven Sjunnesson, "Återbesök med blandade känslor," Tenaestelin: Medlemsblad för svensk-etiopiska föreningen 41, no. 2 (2000), 13.

52 Ibid.

53 Hjelm, "Final Report at Wondo Genet," 6.

541995 omorganiserades den svenska biståndsmyndigheten, och den nya organisationens namnförkortning skrivs med gemener. 
skogsutbildning. Redan i diskussionen kring en eventuell förlängning av projektet under 1999 noterade Sida-representanter ungefär samma sak som Birger Hjelm sedan uttryckte i sin rapport två år senare, nämligen att stödet till Wondo Genet var "svagt ur fattigdomsperspektiv" och att det inte fanns någon tydlig koppling mellan akademisk utbildning och att bekämpa avskogning, vilket var det övergripande målet med verksamheten och ett medel för fattigdomsbekämpning. För första gången inledde Sida, i sin roll som uppdragsgivare, en explicit diskussion inte bara om projektets övergripande utformning utan om dess själva kärna: uppfattningen att högre skoglig utbildning var en viktig utvecklingsfaktor. För fortfarande efter närmare femton års verksamhet var det uppenbarligen svårt att visa på tydligt positiva resultat bortom det rent akademiska samarbetet. ${ }^{55}$

Denna diskussion kom sedan att karaktärisera de sista tio åren av projektet. Den kom till tydligt uttryck i Sidas ambitioner att förstärka forskningsdelen av projektet i samband med att fakulteten flyttade till Wondo Genet, med särskilt fokus på mer samhällstillvänd och direkt avnämarorienterad skoglig forskning. En del av arbetet innebar, som jag nämnde ovan, att ett stort antal av de etiopiska lärarna erbjöds forskarutbildning genom SLU. År 2003 hade Wondo Genet fyra lärare med svenska doktorsexamina på plats, nio genomgick forskarutbildning i Sverige, och ytterligare tre stipendier fanns att dela ut. ${ }^{56}$ Men trots denna omfattande satsning gjordes knappast några framsteg när det gällde att få till stånd den slags forskning Sida prioriterade. En utvärdering av projektet från 2003 påpekade att doktorandernas ämnen var naturvetenskapliga och inriktade mot traditionell skoglig forskning, och att doktorandprogrammet således inte hade gett colleget den bredare personalprofil som eftersträvades. ${ }^{57}$

Samtidigt som man erbjöd forskarutbildning i Sverige arbetade SLU även med att starta upp forskning på plats vid Wondo Genet. I en artikel publicerad i skolans nyhetsbrev år 2000 beskrev dekanus Tesfaye Teshome, Sven-Gunnar Larsson och den svenska skogsexperten Daag Skoog ett ambitiöst mål om att introducera interdisciplinär och lokalbefolkningsanknuten verksamhet både inom forskning och inom utbildning. De menade att både naturvetenskap och samhällsvetenskap behövdes för att lösa problem som rörde naturresursutnyttjande, och att det därför var nödvändigt med "holistiska" angreppssätt som komplement till de mer disciplinbundna perspektiven..$^{58}$ Men i praktiken blev det inte mycket av denna plan. Många av de mer erfarna lärarna var i Sverige för sin forskarutbildning, vilket ledde till personalbrist. Dessutom var de flesta av de potentiella etiopiska forskarna akademiskt inriktade och föredrog traditionella, disciplinbaserade problem framför aktionsforskning och tvärvetenskapligt arbete. Utvärderingen från 2003 slog fast att ett av målen för den senaste projektperioden hade varit att få till stånd ökad interdisciplinaritet och större medverkan från traktens bönder, men att det inte hade lyckats. Istället hade

55 Mötesprotokoll angående 1) Skogsutbildning i Etiopien 2) Stöd till IPPF, 2-3, 21 maj 1999, Sida, mapp NATUR 1999-2236.

56 "Sida Support to Wondo Genet College of Forestry: Final Report by a Review and Appraisal Mission, February/March 2003," 7, 15 juli 2003, Sida, mapp NATUR 1999-2236.

57 "Sida Support to Wondo Genet," i-ii.

58 Tesfaye Teshome, Sven-Gunnar Larsson och Daag Skoog, "The Only Forestry College in Ethiopia," Wondo Genet Newsletter 1, vol. 1 (2000), 2, Förvaltningensavdelningens i Umeå arkiv, F3a: 1, Sveriges lantbruksuniversitets arkiv. 
de projekt som utförts varit "klassiska" naturvetenskapliga studier utan något lokalt deltagande, och hade för övrigt i många fall inte slutförts. Utvärderingen noterade också att SLU:s engagemang för det interdisciplinära arbetet hade varit begränsat. Mönstret var således detsamma både när det gällde doktorandutbildningen i Sverige och forskningen vid Wondo Genet, och det ligger nära till hands att dra slutsatsen att SLU - som också i grunden hade en disciplinbaserad kultur och mycket lite av den samhällsvetenskapliga kompetens som egentligen hade behövts för att uppnå de bredare målen - saknade ordentliga förutsättningar för att stödja den verksamhet Sida efterfrågade.$^{59}$ Den etiopiska silvi-kultur som institutionaliserades vid Wondo Genet blev därmed en teoretisk, akademisk och disciplinbaserad silvi-kultur, som varken reflekterade SLU:s fokus på en kombination av teori och praktik eller Sidas intressen i tvärvetenskaplig aktionsforskning med deltagande från lokalbefolkningen.

Kring 2003 var situationen således komplex och mångfacetterad. Å ena sidan kunde projektet visa upp ett flertal framgångar. Wondo Genet var på väg att bli en självständig akademisk fakultet med eget ansvar för ett antal skogliga kandidat- och masterutbildningar. Antalet anställda med högre akademiska examina hade ökat markant och skulle fortsätta öka allt eftersom fler nydisputerade lärare återvände från Sverige. I ljuset av detta beskrev utvärderingen från samma år Wondo Genet som en ledande akademisk institution på naturresursområdet. ${ }^{60}$ Men eftersom det fanns få nedsippringseffekter och rentav en del som talade för att akademiseringen av Wondo Genet snarast motverkade projektets målsättningar om att bekämpa avskogning och att generera kunskap av relevans för den lokala befolkningen, var den synbara framgången likväl problematisk för finansiärerna på Sida och rådgivarna på SLU, som båda hade anledningar att vara besvikna på den silvi-kultur som nu dominerade på skolan. SLU:s praktiska skogsutbildningsmodell hade inte slagit rot, det lokala deltagande Sida efterfrågade hade inte kommit till stånd, och skogsskötselproblemen antydde att det inte fanns något självklart samband mellan akademisk utbildning och det hållbara och rättvisa utnyttjandet av naturresurser som man ytterst syftade till. Detta innebar ett fundamentalt problem för projektet, som Birger Hjelm redan hade formulerat i sin rapport ett par år tidigare: "One reflection and a fair question: If all or most of the input goes to already privileged groups, how is this meeting up to Sida's main objective: the fighting of poverty?"

SLU kom emellertid att fortsätta stödja Wondo Genet i ytterligare ett halvt årtionde, och under denna sista period gjorde man ett mer genomgripande försök att överbrygga klyftan mellan den akademisk-teoretiska silvi-kulturen och biståndets mål genom ett program som i viss mån lyckades stimulera en del aktionsforskning med lokalt deltagande. Här finns inte utrymme att analysera denna utveckling närmare. Det kan dock sägas att även detta initiativ drogs med problem och förseningar, och det lyckades i slutändan inte övertyga Sida, som valde att avsluta det svenska biståndet till Wondo Genet under 2009. SLU avslutade då också sitt engagemang, och den aktionsforskning som hade inletts fasades ut.

59 "Sida Support to Wondo Genet," 9.

60 Ibid., i. 


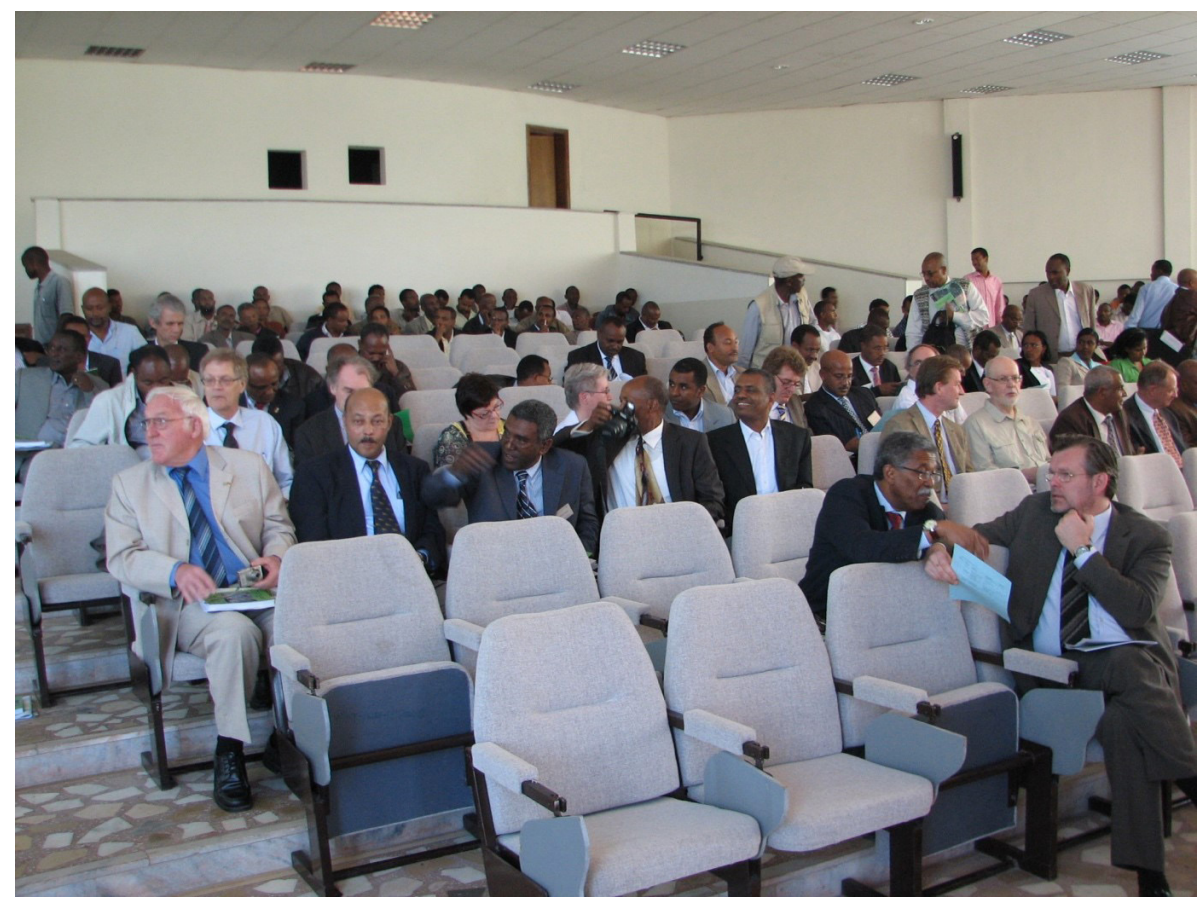

Figur 3. Den nya konferenslokalen och föreläsningssalen i Wondo Genet under ett seminarium i samband med projektets avslutning 2009. Den utgör ett exempel på de stora investeringar som Sida bidrog till när Wondo Genet utvecklades till akademisk institution, men kan samtidigt sägas symbolisera hur den teoretiska undervisningen kom att betonas allt mer. Foto: Sven Sjunnesson, 2009.

\section{Avslutning}

Akademisk utbildning producerar och reproducerar kunskap, färdigheter och värderingar. I föreliggande artikel har jag undersökt sådan reproduktion inom ramen för Sveriges lantbruksuniversitets engagemang i ett svenskt skogligt biståndsprojekt i Etiopien. Min diskussion av tre olika silvi-kulturella möten inom ramen för biståndsprojektet har visat hur detta projekts mest centrala drag var SLU:s mycket starka uppfattning om akademisk skogsutbildning som en delvis praktikbaserad aktivitet kopplad till skogen som en konkret, fysisk plats. Detta utgjorde en bärande anledning till att SLU utformade utbildningsprogram som innehöll en termin i Sverige, där det fanns stora skogsområden som lämpade sig väl för praktiska övningar. I Etiopien saknades i stort sett sådana förutsättningar. Under planeringen för SLU:s samarbete med lantbruksuniversitetet i Alemaya ställdes detta på sin spets: kring Alemaya fanns ingen skog överhuvudtaget. Utifrån den kunskap och de värderingar SLU betraktade som centrala för skogsutbildning kunde man således inte fullt ut acceptera Alemaya som en lämplig plats för denna slags aktivitet.

Diskussionerna kring förutsättningarna för skoglig utbildning vid Alemaya utgör därmed det tydligaste exemplet på hur de svenska experterna guidades av en förförståelse formad inom ramen för en svensk silvi-kultur som kännetecknades av en stark skogsindustri och av hög tillgänglighet till skogsmiljöer för de flesta i befolkningen. Det var i detta sammanhang som uppfattningen om praktikens centralitet även för högsta möjliga skogsutbildning hade utvecklats. I Etiopien var situationen 
helt annorlunda. Där fanns mycket lite sammanhängande skog, ingen skogsindustri att tala om, inga traditioner av skoglig utbildning, och allmänt en stark teoriorientering inom närliggande vetenskapsområden, som till exempel jordbruksvetenskaperna. De svenska experterna uttryckte tydligt uppfattningen att det var av central vikt att anpassa skoglig utbildning till rådande förutsättningar, och att deras förslag karaktäriserades av sådan anpassning. Emellertid har min analys visat att de regelmässigt förbehöll sig rätten att själva avgöra vilka de rådande förutsättningarna var, och att de då tenderade att falla tillbaka på vissa förgivettagna föreställningar som präglade den svenska silvi-kulturen och som i själva verket byggde på de förutsättningar som fanns i Sverige. Här kan man ana ett mer generellt dilemma för det slags kunskapsöverföring jag har diskuterat här: är man för djupt rotad i sin egen expertis är det svårt att kritiskt ifrågasätta den, samtidigt som det är sådana djupa rötter - det vill säga mycket erfarenhet och en långt utvecklad professionalitet - som gör en person till en god kandidat för ett inflytelserikt expertuppdrag.

Detta visar på värdet av att studera utbildningshistoria i en biståndskontext. I mötet med nya miljöer artikulerade SLU:s experter en skoglig utbildningsmodell som tydligt kommunicerade deras uppfattning om vad skoglig expertis innebar. Denna uppfattning, med dess underliggande värderingar, var förvisso inte dold i den inhemska kontexten, men genom att studera hur den förflyttades till en miljö där förutsättningarna var annorlunda går det att se mönster som inte framträder på samma sätt i Sverige. De svenska experternas mycket starka ovilja att nedprioritera praktiken tydliggör exempelvis hur, ur deras perspektiv, akademisk skoglig utbildning var närmast oupplösligt förbunden med praktiskt arbete i skogen. Samtidigt visar studien också på hur utbildningshistoriska undersökningar kan bidra till policydiskussioner, genom att till exempel ifrågasätta uppfattningar om möjligheten för svenska experter att snabbt anpassa sin kunskap till nya omständigheter. Detta ska inte läsas som ett argument mot att bygga upp utbildningsstöd och samarbeten utifrån den modell man är bekant med: poängen, som jag antydde ovan, är att det kan vara svårt att kritiskt granska sin egen expertis, och att självreflexion över detta dilemma är nödvändigt, inte minst inom ramen för brett formulerade visioner som den ovan nämnda om Skogsriket. Om detta inte görs finns risken att man fastnar i sina egna utgångspunkter och får svårt att ta till sig uppfattningar som är värdefulla men som ligger utanför det egna paradigmet. I denna artikel exemplifieras det väl av Badege Bishaws idéer om vilken typ av skogsutbildning som Etiopien behövde. Badege fick begränsat gehör för sina tankar, men den senare utvecklingen antyder att hans uppfattning var framsynt. En liknande slutsats kan också dras ur den över tid alltmer uttalade spänningen mellan SIDA/Sida:s biståndspolitiska mål, för vilka skogsutbildningen var tänkt att vara ett medel, och de resultat projektet faktiskt uppnådde. Först när Sida började kritisera en med tiden alltmer tydlig brist på koppling mellan medel och mål, och det rentav uppstod tvivel om projektets framtida finansiering, stimulerades en reflektion över den egna kunskapen inom SLU som i viss mån också förde projektet in på ett nytt och potentiellt (om än inte fullt ut realiserat) mer produktivt spår under dess sista period.

Det var inte enbart i skogen som svenskt bistånd tillmätte avgörande vikt till praktiskt kunnande. Även om den historiska forskningen på området är begränsad kan man lätt identifiera ett sådant mönster om man till exempel bläddrar bland bi- 
ståndsarbetares egna minnen. ${ }^{61}$ Här utkristalliserar sig en vidare forskningsfråga om svenskt utbildningsbistånd och svenska eller kanske skandinaviska uppfattningar om vad utbildning på olika nivåer, inklusive den akademiska, kan och bör innebära. Vilken vikt tillmättes praktiken på olika utbildningsområden och -nivåer, och varför? Hur påverkade det biståndets utförande? Visst material för sådana jämförelser finns redan i och med min egen forskning om andra agrara biståndsprojekt. ${ }^{62} \mathrm{I}$ det sammanhanget förstår jag SLU:s skogliga engagemang som kongruent med en överordnad svensk agrar ideologi som genomgående betonade vikten av praktiskt och platsbundet kunnande, "residential knowledge", med vetenskapshistorikern Robert Kohlers begrepp. ${ }^{63}$ Teoretisk och praktisk kunskap sågs som kompletterande snarare än som motpoler, och det fanns ingen motsättning mellan att vara expert och arbeta praktiskt. Denna ideologi gav ofta goda resultat i agrara biståndssammanhang, åtminstone i rent teknisk mening, men samtidigt genererade den som regel olika slags friktion när den praktiserades i nya miljöer där föreställningar om expertis såg annorlunda ut och förutsättningarna för dess tillämpning varierade. Kring denna friktion finns utrymme för vidare forskning i gränslandet mellan utbildnings- och biståndshistoria, som kan fortsätta att tydliggöra och analysera svenska utbildningsideologier och deras effekter också på andra områden än det agrara.

61 Se t.ex. bidragen i antologin ...och världen växte: Biståndet som vi minns det, red. Peter Gumbel, Bo Kärre och Anna Wieslander (Uppsala: Sida-seniorerna, 1999).

62 Bruno (2016), särskilt kap. 2; Bruno (2014).

63 Robert E. Kohler, All Creatures: Naturalists, Collectors, and Biodiversity, 1850-1950 (Princeton: Princeton University Press, 2006), 156-62. 


\section{Referenser \\ Otryckta källor}

Riksarkivet

SIDA:s biståndskontors i Etiopien arkiv (SIDA-ETI).

SIDA:s centralarkiv (SIDA).

Sveriges lantbruksuniversitets arkiv

Förvaltningsavdelningens i Umeå arkiv.

Sidas arkiv

\section{Tryckta källor och litteratur}

Adas, Michael. Dominance by Design: Technological Imperatives and America's Civilizing Mission. Cambridge: Belknap Press of Harvard University Press, 2006.

Bagchi, Barnita, Eckhardt Fuchs och Kate Rousmaniere. "Connecting Histories of Education: Transnational and Cross-Cultural Exchanges in (Post-)Colonial Education." I Connecting Histories of Education: Transnational and Cross-Cultural Exchanges in (Post-)Colonial Education, red. Barnita Bagchi, Eckhardt Fuchs och Kate Rousmaniere. New York: Berghahn Books, 2014.

Bendz, Mårten. "Forests and Forestry in Ethiopia." Växjö: Rural Development Consultants, 1988.

Bruno, Karl. "Nils Lagerlöf och det tidiga svenska biståndet." Personhistorisk tidskrift 110, nos. 1-2 (2014), 29-46.

Bruno, Karl. Exporting Agrarian Expertise: Development Aid at the Swedish University of Agricultural Sciences and Its Predecessors, 1950-2009. Uppsala: Sveriges lantbruksuniversitet, 2016.

Burke, Catherine, Peter Cunningham och Ian Grosvenor, red. '”Putting Education in Its Place': Space, Place and Materialities in the History of Education." Specialnummer, History of Education 39, no. 6 (2010).

Bylund, Sven-Olov. "Lämnar Wondo Genet efter 30 år." Resurs, no. 3 (2009): 18-19.

Bäckström, Per-Ove, Johan Toborn och Marianne Wibom. "SUAS Forestry Mission to Ethiopia: B.Sc. Forestry Training at Wondo Genet; Forestry Training at the Agricultural University of Alemaya (AUA); Prospects for Cooperation between AUA and SUAS; Final Report." Uppsala: Sveriges lantbruksuniversitet, 1988.

Bäcktorp, Ann-Louise. When the First-World-North Goes Local: Education and Gender in Post-Revolution Laos. Umeå: Umeå universitet, 2007.

Cronqvist, Marie. "Spatialisera alltid! Rummets återkomst i de historiska vetenskaperna." Scandia 74, no. 2 (2010), 9-14.

Dahlqvist, Anders. "Skogslärare i Etiopien: Ilska, glädje, men aldrig tråkigt." U-landsskogisen 11 (1983), 10-11.

Eriksson Baaz, Maria. "Biståndet och partnerskapets problematik." I Sverige och de Andra: Postkoloniala perspektiv, red. Michael Mc Eachrane och Louis Faye. Stockholm: Natur och Kultur, 2001.

Fahlström, Karin. "Etiopiens förste skogsdekanus." U-landsskogisen 17 (1989), 7-8.

Friis Bach, Christian, Thorsten B. Olesen, Sune Kaur-Pedersen och Jan Pedersen. Idealer og realiteter: Dansk udviklingspolitiks historie 1945-2005. Köpenhamn: Gyldendal, 2008. 
Gessesse Dessie och Menfese Tadesse. "Rethinking Forestry and Natural Resources Higher Education in Ethiopia: An Education for Sustainable Development Perspective." Southern African Journal of Environmental Education 29 (2012/2013), 216-44.

Gumbel, Peter, Bo Kärre och Anna Wieslander, red. ...och världen växte: Biståndet som vi minns det. Uppsala: Sida-seniorerna, 1999.

Heyneman, Stephen P. och Bommi Lee. "International Organizations and the Future of Education Assistance." International Journal of Educational Development 48 (2016), 9-22.

Holmgren, Sara och Seema Arora-Jonsson. "The Forest Kingdom - With What Values for the World? Climate Change and Gender Equality in a Contested Forest Policy Context." Scandinavian Journal of Forest Research 30, no. 3 (2015), 235-45.

Kohler, Robert E. All Creatures: Naturalists, Collectors, and Biodiversity, 1850-1950. Princeton: Princeton University Press, 2006.

Landahl, Joakim. "Det nordiska skolmötet som utbildningspolitisk arena (18701970): Ett rumsligt perspektiv på den moderna pedagogikens historia." Utbildning och demokrati 24, no. 3 (2015), 7-23.

Lundgren, Björn, Reidar Persson och Sten Norén. "Swedish-African Forest Relations." Kungl. Skogs- och Lantbruksakademiens tidskrift 150, no. 2 (2011), 3-82.

Lundh Nilsson, Fay. "De specialiserade yrkesutbildningarna: Exemplet skoglig utbildning." I Yrkesutbildningens formering i Sverige 1940-1975, red. Peter Håkansson och Anders Nilsson. Lund: Nordic Academic Press, 2013.

Mårald, Erland och Christer Nordlund. "Förord.” I Topos: Essäer om tänkvärda platser och platsbundna tankar, red. Erland Mårald och Christer Nordlund. Stockholm: Carlssons, 2006.

Mählck, Paula och Måns Fellesson. "Capacity-Building, Internationalisation or Postcolonial Education? Space and Place in Development-Aid-Funded PhD Training." L'Education Comparée 15 (2016), 97-118.

Odén, Bertil. Biståndets idéhistoria: Från Marshallhjälp till millenniemål. Lund: Studentlitteratur, 2006.

Persson, Reidar. Assistance to Forestry: Experiences and Potential for Improvement. Jakarta: Center for International Forestry Research, 2003.

Rostow, Walt Whitman. The Stages of Economic Growth: A Non-Communist Manifesto. Cambridge: Cambridge University Press, 1960.

Sandewall, Mats. "Skoglig utbildningssatsning i Etiopien - Vad blev utfallet?" Fakta skog - Rön från Sveriges lantbruksuniversitet, no. 9 (2014).

Simensen, Jarle, Arild Engelsen Ruud, Kirsten Alsaker Kjerland och Frode Liland. Norsk utviklingshjelps historie. 3 vol. Bergen: Fagbokforlaget, 2003.

Sjunnesson, Sven. "Återbesök med blandade känslor." Tenaestelin: Medlemsblad för svensk-etiopiska föreningen 41, no. 2 (2000), 12-13.

Stridsberg, Einar och Leif Mattsson. Skogen genom tiderna: Dess roll för lantbruket från forntid till nutid. Stockholm: LT, 1980.

Sutton, Francis X. "Development Ideology: Its Emergence and Decline." Daedalus 118 , no. 1 (1989), 35-60.

Tabulawa, Richard. "International Aid Agencies, Learner-Centred Pedagogy and Political Democratisation: A Critique." Comparative Education 39, no. 1 (2003), $7-26$. 
Toborn, Johan. "Etiopien: 'ett SLU-land"' I Sammanhang: SLU 25 år, red. Gunilla Ramberg. Uppsala: Sveriges lantbruksuniversitet, 2002.

Toborn, Johan. "SLU och etiopisk skogsutbildning: En fråga om att lära eller läras." Skog och forskning 96, no. 1 (1996), 58-65.

Åkerlund, Andreas. "For Goodwill, Aid and Economic Growth: The Funding of Academic Exchange through the Swedish Institute, 1945-2010." Nordic Journal of Educational History 2, no. 1 (2015), 119-40.

Åkerlund, Andreas. "The Impact of Foreign Policy on Educational Exchange: The Swedish State Scholarship Programme 1938-1990." Paedagogica Historica 50, no. 3 (2014), 390-409. 